\title{
The Prevalence, Antibiotic Resistance Pattern, and Associated Factors of Bacterial Vaginosis Among Women of the Reproductive Age Group from Felege Hiwot Referral Hospital, Ethiopia
}

\section{Abebaw Bitew \\ Abeba Mengist $\mathbb{D}$ \\ Habtamu Belew \\ Yibeltal Aschale (iD \\ Alemayehu Reta}

Department of Medical Laboratory Science, College of Medicine and Health Sciences, Debre Markos University,

Debre Markos, Ethiopia
Correspondence: Abebaw Bitew Tel +25l 912477495

Email abebawbit05@gmail.com
Background: Bacterial vaginosis is an infection of the vagina, which results due to change in the normal balance of vaginal bacteria. The aim of this study was to assess the magnitude and determinants of bacterial vaginosis among women of reproductive age group from Felege Hiwot Referral Hospital.

Materials and Methods: A cross-sectional study was conducted among women during the reproductive period at Felege Hiwot Referral Hospital from September 1, 2019 to October 2020. About 413 vaginal swab samples were collected and examined using the Nugent scoring system and culture. Data were analyzed by SPSS version 25 . The odds ratio (OR) was used as a measure of the strength of association and reported with $95 \%$ confidence intervals. $P$-value $\leq 0.05$ was considered to be statistically significant. Bivariate and multivariate logistic regression models were used to identify possible associated factors with bacteria causing bacterial vaginosis.

Results: The overall prevalence of bacteria causing bacterial vaginosis was $39.5 \%$. The predominant bacteria were $S$. aureus $(25.4 \%)$, G. vaginalis $(22.7 \%), S$. agalactiae $(14.1 \%)$, and E. coli (13.5\%). S. aureus was resistant to erythromycin (69.8\%) and trimethoprim/ sulfamethoxazole (53.5\%); despite this, it was susceptible to ciprofloxacillin (93\%), gentamycin $(93 \%)$, and cefoxitin $(90.7 \%)$. On the other hand, E. coli was resistant to trimethoprim/sulfamethoxazole $(91.3 \%)$ and ceftriaxone $(63.6 \%)$, but was susceptible to ciprofloxacillin $(95.5 \%)$ and gentamycin $(93 \%)$.

Conclusion: The high prevalence of bacterial vaginosis was significantly associated with the $\mathrm{pH}$ level of the vagina $(\geq 4.5)$, participant age $\leq 20$, pregnancy, and history of HIV infection. Therefore, early identification of factors leading to bacterial overgrowth on the vagina is very important to protect maternal and child morbidity and mortality.

Keywords: aerobic bacteria, bacterial vaginosis, Gardnerella vaginalis, Lactobacillus

\section{Background}

Bacterial vaginosis is the condition that occurs when the balance of the vaginal flora (normal hydrogen peroxide $\left(\mathrm{H}_{2} \mathrm{O}_{2}\right)$ producing Lactobacillus species) is dysregulated, and replaced by high concentrations of bad bacteria in the vagina like Gardnerella vaginalis,Prevotella, Mobiluncus, and Bacteriodes species, ${ }^{1}$ and some aerobic bacteria occasionally E. coli, S. aureus, E. faecalis, and group B streptococcus (GBS) cause aerobic vaginitis ${ }^{1-4}$ and vulvo-vaginal candidiasis. ${ }^{5}$ 
Bacterial vaginosis was first reported by Gardner and Dukes in 1955. ${ }^{6,7}$ Bacterial vaginosis is the most common cause of vaginitis and associated with preterm labor, premature rupture of membranes and spontaneous abortion, chorioamnionitis, cervicitis, endometritis, urinary tract infections, cervical intraepithelial neoplasia, pelvic inflammatory disease (PID), and delivery of low-birth-weight infants. $^{8,9}$ About $50-75 \%$ of women with BV are asymptomatic; ${ }^{10}$ however, some of the symptoms of BV are characterized by thin white discharge, fishy odor noticeable during menstruation and after sex, vulval or vaginal irritation, or soreness. ${ }^{11,12}$

The lower genital tract microbiota is a dynamic bacterial community that is influenced by many aggravating factors, like age, smoking habit, alcohol use, increased number of sex partners, menopausal period, use of hormonal contraception, and the presence of acute and chronic infections. ${ }^{13,14}$ In a recent study, BV has been significantly associated with HIV infection. $\mathrm{BV}$ is increased by $60 \%$ if the women are HIV positive; and $\mathrm{HIV}$ is increased by $40 \%$ if the women are $\mathrm{BV}$ infected. ${ }^{15}$ Bacterial vaginosis is increased by HSV2 infection, because HSV2 infection promotes a reduction of the normal vaginal lactobacilli. ${ }^{16}$ Being pregnant is one of the most significant associated factors to $\mathrm{BV} .^{17}$ The most significant and recent risk factor in the incidence of $\mathrm{BV}$ is the use of multiple and the same-sex partners, which is suggested as a trigger of BV by disruption of the normal vaginal flora through exposure to alkaline semen, tampon use, clothes sharing, herbs, and flowers. ${ }^{18}$ This problem worsened in the community by leading different complications like preterm labor, infertility, abortion leading to fetal loss, chorioamnionitis, cervicitis, endometritis, urinary tract infections, and others. ${ }^{19}$

Globally, the overall prevalence of BV was over $29.2 \%$, among women aged 14-49 years. $^{20}$ In white women the prevalence of $\mathrm{BV}$ was $23 \%$, whereas in Mexican Americans it was 32\%. ${ }^{21}$ In African-American women the prevalence of BV was about $51 \%$, which is too high. ${ }^{10}$ In sub-Saharan African, the prevalence of BV was $50 \%{ }^{22}$ An estimate of 75,000 maternal deaths were reported annually in the world, the majority of them in resource-limited countries. ${ }^{17}$ According to the global report, more than 2.6 million antibiotic-resistant bacterial infections and 44,000 deaths were reported annually. ${ }^{23,24}$ The emergence and spread of antibiotic-resistant pathogens are a major public health issue today, which requires a global action in order to control further complications. ${ }^{25}$
A single study in Addis Ababa showed 48.6\% of BV prevalence, because as yet studies are limited in our country. ${ }^{26}$ The cause and associated risk factors of BV are not well studied in Africa, especially in Ethiopia there are no well-structured data showing the causative agent, its prevalence, antibiotic resistance pattern, and associated factors of $\mathrm{BV}^{27}$ This is due to limitation of resources to fulfill diagnostic materials for both aerobic and anaerobic culture and treatment centers, and researchers were not rising their interest to do research on BV during the last decade. ${ }^{28}$ As a result of those factors, the resource-limited countries are suffering a lot of maternal morbidity, disability, and death. Therefore, we were initiated to do this research on BV during women's reproductive age. Early diagnosis and treatment are used for the prevention and control mechanisms of BV. Understanding how and what factors are aggravated BV is essential to set a prevention and control strategy for BV. In order to prevent and control the prevalence and burden of $\mathrm{BV}$, noticeable research findings should be required, because the previous and current finding makes a sound to policymakers to move the resource towards the area having the problem and adjust preventive mechanisms. Therefore, the aim of the current study was to assess the prevalence, antibiotic resistance pattern, and associated factors of bacterial vaginosis among women of reproductive age, from Felege Hiwot Referral Hospital, Ethiopia.

\section{Materials and Methods Study Design and Period}

A cross-sectional study was conducted from September 1, 2018 through October 2019 at Felege Hiwot Specialized Referral Hospital in Amhara Region Northwest Ethiopia. Felege Hiwot Specialized Referral Hospital is the only specialized hospital in Bahir Dar, which has wellstandardized microbiology laboratory for bacterial culture, Gram stain, and molecular laboratory for HIV viral load detection.

\section{Study Participants}

The participants were HIV positive and pregnant, were suspected of bacterial vaginosis during the study period, and had no history of antibacterial therapy within two weeks prior to sample collection. Women having genital malignancy, used vaginal cream or ointment product, spermicides and vaginal lubricants or feminine sprays within 72 hours were excluded from this study. 


\section{Sample Size}

The sample size was calculated using a single population proportion formula and considering the following assumptions such as, prevalence $(\mathrm{P})=50 \%$ (since there is no previous study to show the prevalence of $\mathrm{BV}$ caused by both $G$. vaginalis and aerobic bacteria, this study was forced to use $50 \%$ prevalence), confidence interval ${ }^{29}$ of $95 \%$, marginal error $(d=0.05 \%), Z=Z$ score for the $95 \%$ confidence intervals $=1.96$, and $10 \%$ non-response rate.

$\mathrm{n}=\mathrm{Z}^{2} \mathrm{p}(1-\mathrm{p}) / \mathrm{d}^{2}=(1.96)^{2} 0.5(0.5) /(0.05)^{2}=384$, and by adding $10 \%$ non-response rate, $\mathrm{n}=384+38$.

The total sample size was 422 , of which 413 study participants were participating in the study. Nine patients were excluded based on the exclusion criteria.

The selected study participants were sampled using a convenience sampling technique because, in the study area, we did not find a list of the population and the case was very sensitive.

\section{Data Collection}

Data were collected after preparing standardized questionnaires and getting ethical clearance from an ethical review committee of Debre Markos University. Well-trained data collectors were used to collect the data based on sociodemographic, gynecological, and clinical variables. The vaginal swab samples were collected from symptomatic women, who are fulfilling the Amsel's criteria at antenatal care service clinic and maternity ward for bacteriological laboratory analysis.

\section{Specimen Collection}

After obtaining informed consent, two vaginal swab samples were collected from the lateral wall or posterior fornix of the vagina in each of the participants by a nursing professional working in the antenatal care service clinic and maternity ward. One sample was used for $\mathrm{pH}$ meter detection and Gram stain (Nugent score test) and the other was used for culture. The swab samples were placed into a clean and dry container and deliver to the microbiology laboratory before 24 hours of collection. ${ }^{30}$

\section{Laboratory Processing for Identification and Isolation of Bacteria}

The laboratory processes were done at the Amhara Public Health Institute and Felege Hiwot Referral Hospital Microbiology Laboratory. The reasons to process at two laboratory sites were due to time saving and comparing inter-laboratory results. The $\mathrm{pH}$ meter measurement was performed at the sample collection site. But Gram stain (Nugent score test) for anaerobic bacteria and culture for aerobic bacteria were performed at the microbiology laboratory diagnostic site as soon as the samples were delivered. After colony growth, biochemical tests were performed to identify the specific isolates. The biochemical tests like catalase, coagulase, CAMP test, bacitracin, and optochin were used for Gram-positive bacteria identification, whereas Kliger's iron agar, indole, motility, citrate agar, and urease tests were used to identify Gramnegative bacteria. ${ }^{31}$ The pure isolates were processed to perform antibacterial susceptibility tests. ${ }^{32}$

\section{Amsel's Test Criteria}

This is a clinical diagnosis using at least 3-4 criteria such as vaginal $\mathrm{pH}>4.5$, color and consistency of the discharge. Vaginal $\mathrm{pH}$ was measured by rolling the swab over a $\mathrm{pH}$ meter strip immediately after swabbing and the color change result was recorded. A homogeneous thin white discharge was observed by the naked eye after swabbing. The whiff test was done by mixing of $10 \%$ $\mathrm{KOH}$ with vaginal discharge and detecting the presence of fishy odor. ${ }^{10}$

\section{Gram Stain and Nugent Scoring System}

Nugent scoring is a golden standard test for BV and vaginal swabs were used to prepare smears on clean, grease-free slides. The smear was allowed to air-dry and then fixed with $95 \%$ acetone alcohol. Then, the smear was Gram stained using Gram stain protocol and read by an experienced microbiologist under a light microscope using the oil immersion objective $(\times 100)$. Slides were read according to Nugent's score as follows: Lactobacillus morphotypes were reported as large Gram-positive bacillus, Gardnerella were reported as small Gram variable bacilli. Using the Nugent scoring technique, score ranged from $0-4$ for Lactobacillus; 0 indicating that $\geq 30$ organisms were found and 4 indicated that no organism were found. In contrast, for Gardnerella a score 0 indicated that no organism were found and 4 indicated that $\geq 30$ organisms were found. A total of numerical score was calculated ranging from $0-10$ for each sample by summing the scores for each of the three morphotypes. The scores were classified into one of the three ranges to define a case of $\mathrm{BV}$; a score in the range 0-3 indicated normal flora, 4-6 indicated mixed vaginal flora, which is not constituted $\mathrm{BV}$, and 7-10 was constituted of $\mathrm{BV}^{33,34}$ 
Gram-stained slides were also examined for Candida species and polymorph nuclear cell (PMN) count for diagnosis of candidiasis and other Gram-positive and Gramnegative bacteria.

\section{Culture}

In this study, an aerobic culture technique was performed, since anaerobic culture facility was not found in the facility. Swabs collected for culture were transported and delivered to the laboratory immediately. The swabs were inoculated on chocolate agar and human blood agar and incubated at $37{ }^{\circ} \mathrm{C}$ for 72 hours within a $5-10 \% \mathrm{CO}_{2}$ humid atmosphere. The swabs inoculated on MacConkey agar were incubated at $37{ }^{\circ} \mathrm{C}$ for 48 hours. Biochemical tests were used to identify specific isolates. For Grampositive isolates; catalase, coagulase, CAMP test, bacitracin, and optochin disk were used. For Gram-negative bacteria; indole, motility, Kliger iron agar test, simmon citrate agar test, urease test, and oxidase test were used.

\section{Antibacterial Susceptibility Test}

Mueller Hinton agar (MHA) media was used for antibacterial susceptibility test. The test was done using a modified KirbyBauer disk diffusion method and interpreted according to the Clinical Laboratory Standard Institute (CLSI) guideline (2018). The following antimicrograms, like penicillin (10 $\mu \mathrm{g})$, cefoxitine $(30 \mu \mathrm{g})$, trimethoprim/sulfamethoxazole (25/ $23.75 \mu \mathrm{g})$, ceftriaxone $(30 \mu \mathrm{g})$, clindamycin $(2 \mu \mathrm{g})$, erythromycin $(15 \mu \mathrm{g})$, gentamycin $(10 \mu \mathrm{g})$, ciprofloxacillin $(5 \mu \mathrm{g})$, tobramycin $(10 \mu \mathrm{g})$, and amoxicillin $(10 \mu \mathrm{g})$, were used. Three to five pure isolates were taken from a pure culture medium and mixed with nutrient broth and wait for 3-5 hours. The mixture was compared with $0.5 \%$ McFarland standard for seeing equivalent turbidity standard. Then, the suspension was inoculated to MHA and allowed to dry for 5-15 minutes. Antibiotic disks were added to MHA $15 \mathrm{~mm}$ away from the edge and $\geq 24 \mathrm{~mm}$ apart from each other and incubated at 37 ${ }^{\circ} \mathrm{C}$ for 18-24 hours. After incubation, the inhibition zone was measured by caliper and interpreted as sensitive, intermediate, and resistant according to the CLSI guideline. The strains of E. coli ATCC 25922 was used as a quality control and was tested each time when susceptibility testing was performed. ${ }^{35}$

\section{Data Management, Analysis, and Presentation}

Data were coded and checked for error and transferred from a questionnaire to a computer file (Epi Data 3.1), and then exported to SPSS version 25 software for statistical analysis. Descriptive statistics were calculated to examine the socio-demographic characteristics of participants with bacterial infection outcome category. Figures and tables were used to present the findings. Odds ratio (OR) was used as a measure of the strength of association and reported with $95 \%$ confidence intervals. ${ }^{8} P$ value $\leq$ 0.05 was considered to be statistically significant. Categorical variables were compared using the Pearson \#x1D712; ${ }^{2}$ test. The bivariate logistic regression model was fitted to identify possible associated factors with bacterial profile and the multivariate logistic regression model was fitted to control the backward stepwise process by taking $p \leq 0.2$.

\section{Data Quality Control}

Daily collected data were recorded and compiled. All steps in data collection and recording were monitored by the principal investigator. The reagents were checked for expiry date and appropriate storage of temperature and humidity. Positive and negative quality control tests were performed. The laboratory protocol was prepared and strictly followed. The quality assurance was ensured with good practice in preparing and reading Gram stains by competent microbiologists. ${ }^{36}$

\section{Operational Definition}

Reproductive age group: the age group of women from 15-49 who can give birth to a child.

\section{Results}

\section{Frequency of Socio-Demographic, Gynecological, and Clinical Variables}

A total of 413 study participants was involved in this study. The majority of participants were orthodox Christian (377 (91.3)), urban dwellers (343 (83.1)), married (341 (82.6)), antenatal care service user pregnant (334 (80.9)), and having their age group from 31-35 years (134 (32.4)); of 134 participants, $68(50.7 \%)$ were positive for bacterial vaginosis. Based on the educational and occupational level, the majority of them were illiterate and a housewife (122 (29.5\%) and 189 (45.8\%) respectively). In this study, some of the clinical variables were assessed for seeing their association with bacterial vaginosis, for instance, $22 \quad(5.3 \%)$ diabetes mellitus, 249 (32.2\%) human immunodeficiency virus, 24 (5.8\%) herpes simplex virus 2, 46 (11.1\%) gonorrhea, and $158(38.3 \%)$ thin white with abnormal odor 
discharge were assessed, of which 59.3\% DM, 35.3\% HIV, $45.8 \%$ HSV2, 54.2\% gonorrhea, and $88.6 \%$ thin white with abnormal odor discharge had been associated with their magnitude (Table 1).

Table I The Characteristics of Socio-Demographic, Gynecological and Clinical Factors

\begin{tabular}{|c|c|c|c|}
\hline S. no & Characteristi & & Frequency \\
\hline 1 & Age & $\begin{array}{l}\leq 20 \\
21-25 \\
26-30 \\
31-35 \\
36-40 \\
\geq 40\end{array}$ & $\begin{array}{l}28(6.8) \\
31(7.5) \\
65(15.7) \\
134(32.4) \\
67(16.2) \\
88(21.3)\end{array}$ \\
\hline 2 & Residence & $\begin{array}{l}\text { Urban } \\
\text { Rural }\end{array}$ & $\begin{array}{l}343(3.1) \\
70(16.9)\end{array}$ \\
\hline 3 & Religion & $\begin{array}{l}\text { Orthodox } \\
\text { Other }\end{array}$ & $\begin{array}{l}377(91.3) \\
36(8.7)\end{array}$ \\
\hline 4 & $\begin{array}{l}\text { Educational } \\
\text { level }\end{array}$ & $\begin{array}{l}\text { Illiterate } \\
\text { I-8 } \\
9-12 \\
\text { Higher }\end{array}$ & $\begin{array}{l}122(29.5) \\
106(25.5) \\
114(27.6) \\
71(17.2)\end{array}$ \\
\hline 5 & $\begin{array}{l}\text { Occupation } \\
\text { type }\end{array}$ & $\begin{array}{l}\text { Housewife } \\
\text { Merchant } \\
\text { Employer } \\
\text { Daily labor }\end{array}$ & $\begin{array}{l}189(45.8) \\
32(7.7) \\
170(41.2) \\
22(5.3)\end{array}$ \\
\hline 6 & Marital status & $\begin{array}{l}\text { Married } \\
\text { Other }\end{array}$ & $\begin{array}{l}34 I(82.6) \\
72(I 7.4)\end{array}$ \\
\hline 7 & Pregnancy & $\begin{array}{l}\text { Yes } \\
\text { No }\end{array}$ & $\begin{array}{l}334 \text { (80.9) } \\
79(19.1)\end{array}$ \\
\hline 8 & DM & $\begin{array}{l}\text { Yes } \\
\text { No }\end{array}$ & $\begin{array}{l}22(5.3) \\
391(94.7)\end{array}$ \\
\hline 9 & HIV & $\begin{array}{l}\text { Yes } \\
\text { No }\end{array}$ & $\begin{array}{l}249(32.2) \\
164(67.8)\end{array}$ \\
\hline 10 & HSV2 & $\begin{array}{l}\text { Yes } \\
\text { No }\end{array}$ & $\begin{array}{l}24(5.8) \\
389(94.2)\end{array}$ \\
\hline 11 & Gonorrhoeae & $\begin{array}{l}\text { Yes } \\
\text { No }\end{array}$ & $\begin{array}{l}46 \text { (II.I) } \\
367(88.9)\end{array}$ \\
\hline 12 & $\begin{array}{l}\text { Types of } \\
\text { discharge }\end{array}$ & $\begin{array}{l}\text { Thin white with abnormal } \\
\text { odor } \\
\text { Flocculent with normal } \\
\text { odor }\end{array}$ & $\begin{array}{l}158(38.3) \\
255(61.7)\end{array}$ \\
\hline 13 & $\mathrm{pH}$ level & $\begin{array}{l}<4.5 \\
\geq 4.5\end{array}$ & $\begin{array}{l}265(64.2) \\
148(35.8)\end{array}$ \\
\hline
\end{tabular}

Abbreviations: DM, diabetes mellitus; HIV, human immunodeficiency virus; HSV2, herpes simplex virus $2 ; \mathrm{pH}$, power of hydrogen.

\section{The Prevalence of Bacteria Causing Bacterial Vaginosis}

Bacterial vaginosis is an inflammation of the vagina due to the overgrowth of bad bacteria in the vagina. The overall prevalence of bacteria which causes bacterial vaginosis was $39.5 \%$. In this study, mainly Nugent scoring, culture test, and biochemical test were used to identify the microorganisms. Indeed, different microbial profile was detected from the vagina during investigation; however, our concern were bacteria, so organisms other than bacteria (like C. albicans and T. vaginalis) were not included in this document, but they were reported to the hospital for better and timely patient management.

In this study, the total of 163 bacterial isolates were identified, of which $22.7 \%$ (37/163) isolates were $G$. vaginalis, which was the only anaerobic bacteria detected by Nugent scoring test. On the other hand, the predominant aerobic bacteria were S. aureus $(25.4 \%)$, S. agalactiae $(14.1 \%)$, and E. coli $(13.5 \%)$, which were detected by culture and species were identified by biochemical test Figure 1.

\section{Drug Susceptibility Pattern of Bacteria}

In this study, drug susceptibility pattern was done only to aerobic bacteria, because the hospital laboratory did not have an anaerobic facility that supports the growth of $G$. vaginalis. The criteria of selecting antibiotics were based on the CLSI 2018 guideline recommendation, the availability of selected drugs on the market, and frequency of drugs prescribed in the area. Therefore, the most important drugs we selected and their antibiotic susceptibility pattern are presented in Table 2 . Most of the Gram-positive bacteria were resistant to erythromycin $(72.2 \%)$, trimethoprim/sulfamethoxazole (55.6\%), and amoxacillin (46.1\%), but susceptible to ciprofloxacillin (92.2\%), gentamycin (91\%), clindamycin (84\%), and cefoxitine (76.3\%). Among Gram-positive bacterial species, $S$. aureus was highly prevalent bacteria and resistant to erythromycin (69.8\%), trimethoprim/sulfamethoxazole (53.5\%), and amoxacillin (39.5\%), but despite this they were susceptible to ciprofloxacillin (93\%), gentamycin (93\%), cefoxitine $(90.7 \%)$, tobramycin $(83.7 \%)$, and clindamycin $(81.4 \%)$. On the other hand, Gram-negative bacteria were resistant to trimethoprim/sulfamethoxazole $(73.4 \%)$ and amoxacillin $(72.2 \%)$, but they were susceptible to ciprofloxacillin (93.5\%), gentamycin (92.3\%), nitrofirantoin (82.6\%), 


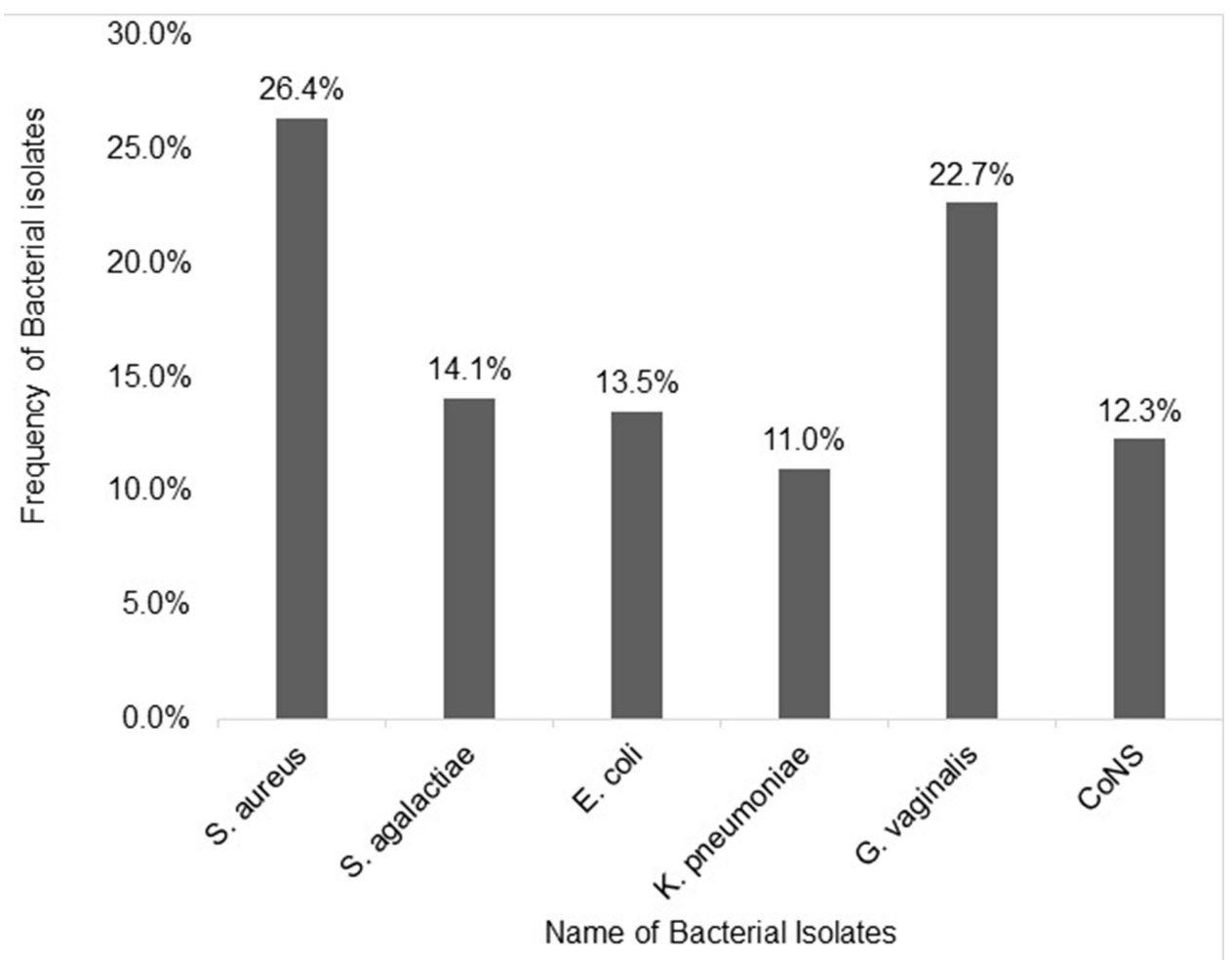

Figure I The Prevalence of Vaginosis Causing Bacteria.

cefoxitine $(58.4 \%)$, and tobramycin $(54.8 \%)$. From $(91.3 \%)$ and ceftriaxone $(63.6 \%)$, but susceptible to Gram-negative bacteria, E. coli were highly prevalent ciprofloxacillin (95.5\%), gentamycin (93\%), and nitrofirbacteria and resistant to trimethoprim/sulfamethoxazole antoin (81.8\%) (Table 2).

Table 2 Percentage of Antibiogram Susceptibility Pattern

\begin{tabular}{|c|c|c|c|c|c|c|c|c|c|c|c|}
\hline \multirow[t]{2}{*}{ Bacterial Species } & \multirow[t]{2}{*}{ Test Result } & \multicolumn{10}{|c|}{ Types of Antibiograms } \\
\hline & & AMOX & CD & Cefoxitine & CER & SXT & CIP & GEN & ER & TOB & $\mathbf{F}$ \\
\hline \multirow[t]{2}{*}{ S. aureus } & $\mathrm{R} \%$ & 39.5 & 18.6 & 9.3 & 20.9 & 53.5 & 7 & 7 & 69.8 & 16.3 & 16.3 \\
\hline & S\% & 60.5 & 81.4 & 90.7 & 79.1 & 46.5 & 93 & 93 & 30.2 & 83.7 & 83.7 \\
\hline \multirow[t]{2}{*}{ S. agalactiae } & $R \%$ & 8.7 & 4.3 & 21.7 & 8.7 & 52.2 & 0 & 0 & 56.5 & 8.7 & 0 \\
\hline & $\mathrm{S} \%$ & 91.3 & 95.7 & 78.3 & 91.3 & 47.8 & 100 & 100 & 43.5 & 91.3 & 100 \\
\hline \multirow[t]{2}{*}{ CoNs } & $\mathrm{R} \%$ & 90 & 25 & 40 & 20 & 60 & 16.3 & 20 & 91.3 & 40 & 35 \\
\hline & $\mathrm{S} \%$ & 10 & 75 & 60 & 80 & 40 & 83.7 & 80 & 8.7 & 60 & 65 \\
\hline \multirow[t]{2}{*}{ Total } & $\mathrm{R} \%$ & 46.1 & 16 & 23.7 & 16.5 & 55.2 & 7.8 & 9 & 72.6 & 21.7 & I7.1 \\
\hline & $\mathrm{S} \%$ & 53.9 & 84 & 76.3 & 83.5 & 44.8 & 92.2 & 91 & 27.4 & 78.3 & 82.9 \\
\hline \multirow[t]{2}{*}{ E. coli } & $\mathrm{R} \%$ & 44.4 & - & 50 & 63.6 & 91.3 & 4.5 & 7 & - & 68.2 & 18.2 \\
\hline & $\mathrm{S} \%$ & 55.6 & - & 50 & 36.4 & 8.7 & 95.5 & 93 & - & 31.8 & 81.8 \\
\hline \multirow[t]{2}{*}{ K. pneumoniae } & $\mathrm{R} \%$ & 100 & - & 33.3 & 38.9 & 55.6 & 8.5 & 8.5 & - & 22.2 & 16.7 \\
\hline & $\mathrm{S} \%$ & 0 & - & 66.7 & 61.1 & 44.4 & 91.5 & 91.5 & - & 77.8 & 83.3 \\
\hline \multirow[t]{2}{*}{ Total } & $\mathrm{R} \%$ & 72.2 & - & 41.6 & 51.2 & 73.4 & 6.5 & 7.7 & - & 45.2 & 17.4 \\
\hline & S\% & 27.8 & - & 58.4 & 48.8 & 26.6 & 93.5 & 92.3 & - & 54.8 & 82.6 \\
\hline
\end{tabular}

Abbreviations: AMOX, amoxacillin; CD, clindamycin; CER, ceftriaxone; SXT, trimethoprim/sulphamoxaxole; CIP, ciprophloxacin; GEN, gentamycin; ER, erythromycin; TOB, tobramycin; F, nitrofirantoin; $R$, resistance; $S$, susceptible. 


\section{Associated Risk Factors}

In this study, different associated factors were assessed using bivariate and multivariate logistic analysis. The significant associated factors were $\mathrm{pH}$ level, age, pregnancy, HIV infection, DM, and discharge type. The $\mathrm{pH}$ level $(\geq 4.5)$ had been 4.3 and 2 times highly increased for bacterial infection than $\mathrm{pH}$ level $<4.5$ in both bivariate $(4.3$ (95\% CI, 2.790, 6.563)) and multivariate $(2(95 \% \mathrm{CI}, 1.031,4.317))$ analysis. The age of the participant, like age $\leq 20$ (7 (95\% CI, 1.57, 31.79)) and age from $31-35(0.5$ (95\% CI, 0.30, 0.92)), pregnancy (1.7 $(1.008,2.705)$ and $4.6(2.179,9.696))$, HIV infection $(1.5$ $(1.031,2.305)$ and $1.8(1.166,2.720))$, types of discharge (0.01 (95\% CI, 0.007, 0.024 and 0.2 (95\% CI, 0.007, 0.032)) were associated with the overgrowth of bacteria from vagina causing bacterial vaginosis. But factors like religion and occupational status were not significantly associated with the overgrowth of bacteria from the vagina, in both bivariate and multivariate logistic regression analysis (Table 3).

\section{Discussion}

Globally, bacterial vaginosis is a public health concern to women especially during the reproductive period. In this study, the prevalence of bacteria, which causes bacterial vaginosis was associated with different factors. About 413 study participants were investigated for bacterial vaginosis, of which the overall prevalence of bacteria which causes bacterial vaginosis was $39.5 \%$. This finding is comparable to studies done in Addis Ababa $(41.5 \%),{ }^{26}$ Kenya

Table 3 Factors Associated with Bacterial Overgrowth in the Vagina

\begin{tabular}{|c|c|c|c|c|c|c|}
\hline \multicolumn{2}{|l|}{ Characteristics } & \multirow{2}{*}{$\begin{array}{l}\text { Frequency (\%) } \\
28(6.8)\end{array}$} & \multicolumn{2}{|c|}{ Bacterial Vaginosis } & \multirow[t]{2}{*}{ COR $(95 \% \mathrm{Cl})$} & \multirow[t]{2}{*}{ AOR (95\% Cl) } \\
\hline & & & Yes (\%) & No (\%) & & \\
\hline Age & $\begin{array}{l}\leq 20 \\
21-25 \\
26-30 \\
31-35 \\
36-40 \\
\geq 40\end{array}$ & $\begin{array}{l}28(6.8) \\
31(7.5) \\
65(15.7) \\
134(32.4) \\
67(16.2) \\
88(21.3)\end{array}$ & $\begin{array}{l}2(7.1) \\
10(32.3) \\
25(38.5) \\
68(50.7) \\
27(40.3) \\
31(35.2)\end{array}$ & $\begin{array}{l}26(92.9) \\
21 \quad(67.7) \\
40(61.5) \\
66(49.3) \\
40(59.7) \\
57(64.8)\end{array}$ & $\begin{array}{l}7(1.57,31.79) \\
I . I(0.48,2.73) \\
0.9(0.45,1.69) \\
0.5(0.30,0.92) \\
0.8(0.42,1.55) \\
I\end{array}$ & \\
\hline Residence & $\begin{array}{l}\text { Urban } \\
\text { Rural }\end{array}$ & $\begin{array}{l}343(83.1) \\
70(16.9)\end{array}$ & $\begin{array}{l}128(37.3) \\
35(50)\end{array}$ & $\begin{array}{l}215(62.7) \\
35(50)\end{array}$ & $\begin{array}{l}1.7(1.00,2.82) \\
\text { I }\end{array}$ & \\
\hline Religion & $\begin{array}{l}\text { Orthodox } \\
\text { Other }\end{array}$ & $\begin{array}{l}377(91.3) \\
36(8.7)\end{array}$ & $\begin{array}{l}\text { I } 48(39.3) \\
\text { I5 (4I.7) }\end{array}$ & $\begin{array}{l}229(60.7) \\
21(58.3)\end{array}$ & $\begin{array}{l}\text { I.I }(0.552,2.2 \mathrm{I} 2) \\
\mathrm{I}\end{array}$ & \\
\hline Occupation type & $\begin{array}{l}\text { Housewife } \\
\text { Merchant } \\
\text { Employer } \\
\text { Daily labor }\end{array}$ & $\begin{array}{l}189(45.8) \\
32(7.7) \\
170(4 \mid .2) \\
22(5.3)\end{array}$ & $\begin{array}{l}92(48.7) \\
10(31.3) \\
52(30.6) \\
9(40.9)\end{array}$ & $\begin{array}{l}97(51.3) \\
22(68.7) \\
118(69.4) \\
13(59.1)\end{array}$ & $\begin{array}{l}0.7(0.298, \text { I.789) } \\
\text { I.5 }(0.49 \text { I, } 4.724) \\
\text { I.6 }(0.632,3.904) \\
\text { I }\end{array}$ & \\
\hline Pregnancy & $\begin{array}{l}\text { Yes } \\
\text { No }\end{array}$ & $\begin{array}{l}334(80.9) \\
79(19.1)\end{array}$ & $\begin{array}{l}124(37.1) \\
39(49.4)\end{array}$ & $\begin{array}{l}210(62.9) \\
40(50.6)\end{array}$ & $\begin{array}{l}\text { I.7 (I.008, 2.705) } \\
\text { । }\end{array}$ & $4.6(2.179,9.696)$ \\
\hline DM & $\begin{array}{l}\text { Yes } \\
\text { No }\end{array}$ & $\begin{array}{l}22(5.3) \\
391(94.7)\end{array}$ & $\begin{array}{l}13(59.3) \\
150(38.4)\end{array}$ & $\begin{array}{l}9(40.7) \\
24 I(61.6)\end{array}$ & $\begin{array}{l}0.4(0.180,1.033) \\
\text { I }\end{array}$ & $\begin{array}{l}0.2(0.065,0.911) \\
1\end{array}$ \\
\hline HIV & $\begin{array}{l}\text { Yes } \\
\text { No }\end{array}$ & $\begin{array}{l}249(32.2) \\
164(67.8)\end{array}$ & $\begin{array}{l}88(35.3) \\
75(45.7)\end{array}$ & $\begin{array}{l}161(64.7) \\
89(54.3)\end{array}$ & $\begin{array}{l}\mathrm{I} .5(\mathrm{I} .03 \mathrm{I}, 2.305) \\
\mathrm{I}\end{array}$ & $\begin{array}{l}\text { I.8 }(1.166,2.720) \\
\text { I }\end{array}$ \\
\hline Gonorrhoeae & $\begin{array}{l}\text { Yes } \\
\text { No }\end{array}$ & $\begin{array}{l}46(11.1) \\
367(88.9)\end{array}$ & $\begin{array}{l}25(54.2) \\
138(37.6)\end{array}$ & $\begin{array}{l}21(45.8) \\
229(62.4)\end{array}$ & $\begin{array}{l}0.5(0.273,0.939) \\
\text { I }\end{array}$ & \\
\hline Types of discharge & $\begin{array}{l}\text { Abnormal odor } \\
\text { Normal odor }\end{array}$ & $\begin{array}{l}158(38.3) \\
255(61.7)\end{array}$ & $\begin{array}{l}140(88.6) \\
23(9)\end{array}$ & $\begin{array}{l}18(11.4) \\
232(91)\end{array}$ & $\begin{array}{l}0.01(0.007, .024) \\
\mathrm{I}\end{array}$ & $\begin{array}{l}0.02(0.007,0.032) \\
\text { I }\end{array}$ \\
\hline $\mathrm{Ph}$ level & $\begin{array}{l}<4.5 \\
\geq 4.5\end{array}$ & $\begin{array}{l}265(64.2) \\
148(35.8)\end{array}$ & $\begin{array}{l}72(27.2) \\
91(61.5)\end{array}$ & $\begin{array}{l}193(72.8) \\
57(38.5)\end{array}$ & $\begin{array}{l}\text { I } \\
4.3(2.790,6.563)\end{array}$ & $\begin{array}{l}\text { I } \\
2(1.031,4.317)\end{array}$ \\
\hline
\end{tabular}

Abbreviations: DM, diabetes mellitus; HIV, human immunodeficiency virus. 
$(43.1 \%),{ }^{37}$ Nigeria (33\%), ${ }^{24,38}$ and Cameroon (38\%). ${ }^{39,40}$ The findings of the present study together with the previous study conducted in Addis Ababa showed a serious concern for women during the reproductive period in Ethiopia.

From a total of $163(39.5 \%)$ confirmed pathogenic bacterial isolates, 37 (22.7\%) were G. vaginalis which is anaerobic bacteria and 126 (77.3\%) were aerobic bacteria. Among aerobic bacteria, nearly 3/4th of them were Gram positive $86(68.3 \%)$ whereas about $1 / 4$ th of them were Gram negative 40 (31.7\%), and these study findings were in line with a study conducted in Addis Ababa. The prevalence of Gram-positive bacteria was 105 (69.5\%) and the prevalence of Gram-negative bacteria was $46(30.5 \%)$. The predominant Gram-positive bacteria were $S$. aureus (43 $(50 \%))$ and $S$. agalactiae (23 (26.7\%)); on the other hand, the predominant Gram-negative bacteria were E. coli $(22$ (55\%)) and $K$. pneumoniae (18 (45\%)). The current study findings were in agreement with studies conducted in India S. aureus (41.07\%), ${ }^{41}$ Addis Ababa E. coli 43 (41\%) and K. pneumoniae $28(30.5 \%),{ }^{26}$ Belgium $^{42}$ and America. ${ }^{43}$ In this study, $22.7 \%(37 / 163)$ of $G$. vaginalis was detected using Nugent's scoring technique. This findings was lower than studies conducted in Cameron $(38 \%)^{44}$ and Gambia $(44.4 \%),{ }^{45}$ but in line with a study conducted in Italy $(26.62 \%){ }^{46}$

Over the last two decades, multidrug-resistant bacteria has been a dramatic surge and the number of pharmaceutical companies developing new antimicrobial agents has declined. ${ }^{29}$ As a result, antibiotic-resistant bacteria are now one of the most pressing health problems and an alarming issue for the world health leaders, especially in resource-limited countries. ${ }^{47}$ In the present study, the drug susceptibility pattern of aerobic bacteria was detected using routine culture media. Gram-positive bacteria were resistant to erythromycin (72.5\%), trimethoprim/sulfamethoxazole $(55.2 \%)$, and amoxacillin $(46.1 \%)$, but susceptible to ciprofloxacillin (92.2\%), gentamycin (91\%), clindamycin (84\%), and cefoxitine (76.3\%); similar findings were reported in Bahir Dar, ${ }^{48}$ Addis $\mathrm{Ababa}^{26}$ and Pakistan. ${ }^{49}$ Among Gram-positive bacteria S. aureus was resistant to erythromycin (69.8\%), trimethoprim/sulfamethoxazole (53.5\%), and amoxacillin (39.5\%), but despite this, they were susceptible to ciprofloxacillin (93\%), gentamycin (93\%), cefoxitine (90.7\%), tobramycin $(83.7 \%)$, and clindamycin (81.4\%). The finding agreed with previous reports in Ethiopia and abroad. ${ }^{50}$ On the other hand, Gram-negative bacteria were resistant to trimethoprim/sulfamethoxazole (73.4\%) and amoxacillin
(72.2\%), but susceptible to ciprofloxacillin (93.5\%), gentamycin (92.3\%), nitrofirantoin (82.6\%), cefoxitine (58.4\%), and tobramycin (54.8\%). Among Gram-negative bacteria, E. coli was the predominant isolated bacteria and resistant to erythromycin (95.5\%), trimethoprim/sulfamethoxazole $(91.3 \%)$, and ceftriaxone $(63.6 \%)$. The current findings were in agreement with a study conducted at Bahir Dar, ${ }^{48}$ Gondar, ${ }^{50-52}$ Addis Ababa, ${ }^{26}$ India, ${ }^{53}$ and Portugal. ${ }^{54}$

Gram-negative bacteria were resistant to most antibiotics more than Gram-positive bacteria, for the reason that the biological structure of Gram-negative bacteria is much harder, which acts as a permeability barrier and is used for drug efflux pumps. ${ }^{47}$ Generally, antibiotic resistance bacteria uses a number of mechanisms like physical removal of the drug from the cell, modification of target site, and modification of the folic acid synthesis pathway to resist the inhibiting effect of drugs. ${ }^{52,55}$ The World Health Organization has a future strategy by focusing on the discovery and development of new antibiotics specifically active against multidrug and extensively drug-resistant Gram-negative bacteria. ${ }^{56}$ So, the local health professionals use the updated antibiotics based on WHO recommendations. In addition, the health professionals must use narrow spectrum drugs based on an antibiotic susceptibility test profile rather than using broad spectrum antibiotics. Furthermore, the health minister of the local country should support this idea and access infrastructures to fulfill the health facility, especially the antenatal care clinic and maternity wards.

In the present study, there was a significant association between bacteria causing $\mathrm{BV}$ and associated factors to the overgrowth of bacteria in the vagina. Among different factors, the $\mathrm{pH}$ level of the vagina ( $\geq 4.5$ ), being pregnant, history of HIV infection, and age of the women showed a significant association with bacterial overgrowth in the vagina and causing $B V$. The vagina $\mathrm{pH}$ level $\geq 4.5$ had been 4 and 2 times significantly associated to BV than $\mathrm{pH}$ level $<4.5$ by using bivariate and multivariate logistic regression analysis respectively. Early age ( $\leq 20$ years) women had been associated with the overgrowth of bacteria in the vagina causing BV. Similar studies were conducted in Addis Ababa, Ethiopia ${ }^{26}$ and a South American population. ${ }^{43}$ Being pregnant was 2 and 5 times significantly associated with $\mathrm{BV}$ in bivariate and multivariate logistic regression analysis respectively. This finding was in agreement with the fact that in the women in physiological change, leading to hormonal change, which is prone 
to vaginal infection during pregnancy, the number of vaginal Lactobacillus was decreased, and this leads to decrease the level of vaginal lactic acid and $\mathrm{H}_{2} \mathrm{O}_{2} \cdot{ }^{57}$ However, the fact is contradicted with a study conducted India in 2016, saying that during the pregnancy period, the vaginal microbiota is conditioned by high estrogen levels and has a good supply of glycogen and a high percentage of lactobacillary flora which significantly reduces the multiplication of pathogenic organisms, due to production of defense factors by lactobacilli. ${ }^{41}$ The women who had a history of previous HIV infection had been 1.5 and 1.8 times highly risked to bacterial overgrowth from their vagina and exposed to $\mathrm{BV}(\mathrm{OR}=1.5(95 \% \mathrm{CI}, 1.031$, $2.305)$ and $\mathrm{OR}=1.8(95 \% \mathrm{CI}, 1.166,2.720))$. This study's findings were different from studies conducted in Nigeria $^{58}$ and America. ${ }^{59}$ This might be due to environmental, socioeconomic, and cultural differences between Ethiopia and abroad. ${ }^{60}$ Based on scientifically proved reason, during HIV infection and pregnancy the immune status of women is decreased, leading to various bacterial infections. ${ }^{52,61}$

However, types of discharge had a significant association with $\mathrm{BV}$, and the association was protective to $\mathrm{BV}$ $(\mathrm{OR}=0.01(95 \% \mathrm{CI}, 0.007,0.024)$ and $\mathrm{OR}=0.02(95 \%$ CI, 0.007, 0.032)). On the other hand, factors like religion and occupational status of the women were not surprisingly associated with $\mathrm{BV}$ in both bivariate and multivariate logistic regression analysis. This is in line with a study conducted in India, ${ }^{62}$ but on the other hand, another study conducted in India had showed religion and occupational status of the women had a significant association to bacterial overgrowth in the vagina and causing $\mathrm{BV} .^{63}$

\section{Limitation}

The limitation of this study was the absence of anaerobic culture and molecular test facility.

\section{Conclusion}

In this study, the Nugent scoring technique and aerobic culture media were used to detect pathogenic bacteria. The overall prevalence of bacteria causing BV was very high. The majority of the isolated bacteria were G. vaginalis, $S$. aureus, GBS, and E. coli and most of them were resistant to most of the drugs routinely prescribed in the hospital, like amoxacillin, cefoxitine, erythromycin, trimethoprim/sulfamethoxazole, and gentamycin. Therefore, early identification of factors which leads to the overgrowth of different bacteria in the vagina and selecting appropriate drugs for the specific bacterial isolate are very important for preventing and controlling the complication of $\mathrm{BV}$ from women during reproductive age.

Based on the current research findings, the authors recommend to the health institutions, especially Felege Hiwot Referral Hospital administrative office and all staffs to give especial attention for women during the reproductive age. Moreover, the health professional do early case identification based on laboratory confirmation and give immediate response as much as possible, because improving the health status of the women leads to improve the community health status indirectly, since the women takes the lion share of the community development both in health and economy. Other researchers should do further longitudinal study by using more advanced technique like anaerobic culture and molecular diagnostic tests.

\section{Abbreviations}

$\mathrm{BV}$, bacterial vaginosis; CVL, cervicovaginal lavage; $\mathrm{H}_{2} \mathrm{O}_{2}$, hydrogen peroxide; IUD, intrauterine device; PID, pelvic inflammatory disease; PMN, polymorphonuclear cell; SPSS, Statistical Package for Social Science; STI, sexually transmitted infection.

\section{Data Sharing Statement}

All data generated and analyses during this study were included in the manuscript.

\section{Ethical Approval and Informed Consent}

This study was conducted in accordance with the Declaration of Helsinki. Ethical clearance was obtained from DebreMarkos University, Institutional Research Ethics Review Committee (IRERC). The research proposal was submitted to DebreMarkos University community and research coordinating office of the health science college to the IRERC. The committee has nine members. The IRERC scrutinized the proposal for ethical issue and made the research to correct and incorporate essential elements. The IRERC were approved the research by a signing ethical approval number (HSC/R/C/Ser/Co/103/ $11 / 11$ ), by the date $18 / 03 / 2019$. Permission was obtained from Felege Hiwot Referral Hospital. The samples taken from the study participants were only for the sake of this study. A written informed consent was obtained from mothers after explaining the purpose and objective of the study. Participants had a full right to continue or withdraw 
from the study. All information was kept confidential by assigned code and assessed only by the principal investigator and supervisors. The laboratory results were communicated with physicians or nurses for the early management of the participants.

\section{Acknowledgments}

First, I would like to thank Debre Markos University to allocate the budget for this research data collection, laboratory processing, and data analysis. We are giving great heartfull thanks to the Medical Laboratory science department and the research group for their technical and material support starting from the beginning to the end. My last but not least acknowledgment is the data collectors and study participants for their volunteer participation during data collection.

\section{Author Contributions}

All authors made a significant contribution to this study reported, whether that is in the conception, study design, execution, acquisition of data, analysis and data interpretation, or in all these areas; took part in drafting, revising or critically reviewing the article; gave final approval of the version to be published; have agreed on the journal to which the article has been submitted; and agree to be accountable for all aspects of the work.

\section{Funding}

Authors received no funding, except Debre Markos University allocate budget for data collection, laboratory processing and data analysis.

\section{Disclosure}

The authors declare that they have no competing interests in this study.

\section{References}

1. Koumans EH, Markowitz LE, Hogan V, group CBw. Indications for therapy and treatment recommendations for bacterial vaginosis in nonpregnant and pregnant women: a synthesis of data. Clin Infect Dis. 2002;35(Supplement_2):S152-S172. doi:10.1086/342103

2. Onderdonk AB, Delaney ML, Fichorova RN. The human microbiome during bacterial vaginosis. Clin Microbiol Rev. 2016;29(2):223-238. doi:10.1128/CMR.00075-15

3. Kaambo E, Africa C, Chambuso R, Passmore J-AS. Vaginal microbiomes associated with aerobic vaginitis and bacterial vaginosis. Front Public Health. 2018;6:78. doi:10.3389/fpubh.2018.00078

4. Donders GG, Vereecken A, Bosmans E, Dekeersmaecker A, Salembier G, Spitz B Aerobic vaginitis: abnormal vaginal flora entity that is distinct from bacterial vaginosis. Paper presented at: International Congress Series; 2005.
5. Gajdács M, Dóczi I, Ábrók M, Lázár A, Burián K. Epidemiology of candiduria and Candida urinary tract infections in inpatients and outpatients: results from a 10-year retrospective survey. Central Eur J Urol. 2019;72(2):209. doi:10.5173/ceju.2019.1909

6. Scott T, Smyth C, Keane C. In vitro adhesiveness and biotype of Gardnerella vaginalis strains in relation to the occurrence of clue cells in vaginal discharges. Sex Transm Infect. 1987;63(1):47-53. doi:10.1136/sti.63.1.47

7. Holst E, Wathne B, Hovelius B, Mårdh P-A. Bacterial vaginosis: microbiological and clinical findings. Eur J Clin Microbiol. 1987;6 (5):536-541. doi:10.1007/BF02014242

8. Donati L, Di Vico A, Nucci M, et al. Vaginal microbial flora and outcome of pregnancy. Arch Gynecol Obstet. 2010;281(4):589-600. doi:10.1007/s00404-009-1318-3

9. Wilson JF. Vaginitis and cervicitis. Ann Intern Med. 2009;151(5): ITC3-1. doi:10.7326/0003-4819-151-5-200909010-01003

10. Bautista CT, Wurapa E, Sateren WB, Morris S, Hollingsworth B, Sanchez JL. Bacterial vaginosis: a synthesis of the literature on etiology, prevalence, risk factors, and relationship with chlamydia and gonorrhea infections. Military Med Res. 2016;3(1):4. doi:10.1186/s40779-016-0074-5

11. Jones A. Bacterial Vaginosis: a Review of Treatment, Recurrence, and Disparities. J Nurse Practitioners. 2019;15(6):420-423. doi:10.1016/j.nurpra.2019.03.010

12. Gajdács M, Zsoldiné Urbán E. Epidemiology and resistance trends of Staphylococcus aureus isolated from vaginal samples: a 10-year retrospective study in Hungary. Acta Dermatovenerologica Alpina Pannonica et Adriatica. 2019;28(4):143-147. doi:10.15570/ actaapa.2019.35

13. Pál Z. Evaluation of role of anaerobic bacteria in gynaecological infections: such as bacterial vaginosis and infections due to long term use of contraceptive intrauterine devices. szte. 2007.

14. Cherpes TL, Hillier SL, Meyn LA, Busch JL, Krohn MA. A delicate balance: risk factors for acquisition of bacterial vaginosis include sexual activity, absence of hydrogen peroxide-producing lactobacilli, black race, and positive herpes simplex virus type 2 serology. Sex Transm Dis. 2008;35(1):78-83. doi:10.1097/ OLQ.0b013e318156a5d0

15. Cohen CR, Lingappa JR, Baeten JM, et al. Bacterial vaginosis associated with increased risk of female-to-male HIV-1 transmission: a prospective cohort analysis among African couples. PLoS Med. 2012;9(6):e1001251. doi:10.1371/journal.pmed.1001251

16. Wright PW, Hoesley CJ, Squires KE, Croom-Rivers A, Weiss HL, Gnann JW. A prospective study of genital herpes simplex virus type 2 infection in human immunodeficiency virus type 1 (HIV-1)seropositive women: correlations with CD4 cell count and plasma HIV-1 RNA level. Clin Infect Dis. 2003;36(2):207-211. doi: $10.1086 / 345440$

17. Brocklehurst P, Gordon A, Heatley E, Milan SJ. Antibiotics for treating bacterial vaginosis in pregnancy. Cochrane Database Sys Rev. 2013. doi:10.1002/14651858.CD000262.pub4

18. Vodstrcil LA, Walker SM, Hocking JS, et al. Incident bacterial vaginosis (BV) in women who have sex with women is associated with behaviors that suggest sexual transmission of BV. Clin Infect Dis. 2015;60(7):1042-1053. doi:10.1093/cid/ciu1130

19. Paavonen J, Brunham RC. Bacterial vaginosis and desquamative inflammatory vaginitis. $N$ Eng $J$ Med. 2018;379(23):2246-2254. doi:10.1056/NEJMra1808418

20. van de Wijgert JH, Jespers V. The global health impact of vaginal dysbiosis. Res Microbiol. 2017;168(9-10):859-864. doi:10.1016/j. resmic.2017.02.003

21. Tolosa JE, Chaithongwongwatthana S, Daly S, et al. The International Infections in Pregnancy (IIP) study: variations in the prevalence of bacterial vaginosis and distribution of morphotypes in vaginal smears among pregnant women. Am J Obstet Gynecol. 2006;195(5):1198-1204. doi:10.1016/j.ajog.2006.08.016 
22. Jespers V, Crucitti T, Menten J, et al. Prevalence and correlates of bacterial vaginosis in different sub-populations of women in sub-Saharan Africa: a cross-sectional study. PLoS One. 2014;9:10. doi:10.1371/journal.pone.0109670

23. Control CfD, Prevention. Antibiotic Resistance Threats in the United States, 2013. Centres for Disease Control and Prevention, US Department of Health; 2013.

24. Javed A, Parvaiz F, Manzoor S. Bacterial vaginosis: an insight into the prevalence, alternative treatments regimen and it's associated resistance patterns. Microb Pathog. 2019;127:21-30. doi:10.1016/j. micpath.2018.11.046

25. Gajdács M. The concept of an ideal antibiotic: implications for drug design. Molecules. 2019;24(5):892. doi:10.3390/molecules24050892

26. Bitew A, Abebaw Y, Bekele D, Mihret A. Prevalence of bacterial vaginosis and associated risk factors among women complaining of genital tract infection. Int J Microbiol. 2017;2017:1-8. doi:10.1155/ 2017/4919404

27. Srinivasan S, Fredricks DN. The human vaginal bacterial biota and bacterial vaginosis. Interdiscip Perspect Infect Dis. 2008;2008.

28. Turovskiy Y, Sutyak Noll K, Chikindas ML. The aetiology of bacterial vaginosis. J Appl Microbiol. 2011;110(5):1105-1128. doi:10.1111/ j.1365-2672.2011.04977.x

29. Nasim MJ, Witek K, Kincses A, et al. Pronounced activity of aromatic selenocyanates against multidrug resistant ESKAPE bacteria New J Chem. 2019;43(15):6021-6031. doi:10.1039/C9NJ00563C

30. Baron EJ. Specimen collection, transport, and processing: bacteriology. Manual Clin Microbiol. 2015;270-315.

31. Bhat S, Devi N, Shenoy S. Microbiological Profile Of Vaginal Swabs. J Evolution Med Dental Sci. 2012;1(4):509-513. doi:10.14260/ jemds $/ 80$

32. Tumuhamye J, Steinsland H, Bwanga F, et al. Vaginal colonization with antimicrobial-resistant bacteria among women in labor in central Uganda: prevalence and associated factors. Antimicrob Resist Infect Control. 2021;10(1):1-11. doi:10.1186/s13756-021-00897-9

33. Mohanty S, Sood S, Kapil A, Mittal S. Interobserver variation in the interpretation of Nugent scoring method for diagnosis of bacterial vaginosis. Indian J Med Res. 2010;131(1):88.

34. Hoffman MK, Bellad MB, Charantimath US, et al. A comparison of colorimetric assessment of vaginal $\mathrm{pH}$ with Nugent score for the detection of bacterial vaginosis. Infect Dis Obstet Gynecol. 2017;2017:1-4. doi:10.1155/2017/1040984

35. Humphries R, Ambler J, Mitchell S, et al. on behalf of the CLSI Methods Development and Standardization Working Group of the Subcommittee on Antimicrobial Susceptibility Testing. 2018. CLSI Methods Development and Standardization Working Group best practices for evaluation of antimicrobial susceptibility tests. J Clin Microbiol. 2018;56:01934.

36. Hemalatha R, Ramalaxmi BA, Swetha E, Balakrishna N, Mastromarino P. Evaluation of vaginal $\mathrm{pH}$ for detection of bacterial vaginosis. Indian J Med Res. 2013;138(3):354.

37. Nzomo J, Waiyaki P, Waihenya R. Bacterial vaginosis and correlates in women of reproductive age in Thika, Kenya. Advances in Microbiology. 2013;03(03):249-254. doi:10.4236/aim.2013.33036

38. Aduloju OP, Akintayo AA, Aduloju T. Prevalence of bacterial vaginosis in pregnancy in a tertiary health institution, south western Nigeria. Pan Afr Med J. 2019;33. doi:10.11604/pamj.2019.33.9.17926

39. Berard A, Birse K, Lamont A, et al. BV-Associated Bacteria Cause Molecular and Physiological Dysfunction of the Vaginal Epithelium. Paper presented at: Aids Research and Human Retroviruses; 2018.

40. Kamga YM, Ngunde JP, Akoachere J-FK. Prevalence of bacterial vaginosis and associated risk factors in pregnant women receiving antenatal care at the Kumba Health District (KHD), Cameroon. BMC Pregnancy Childbirth. 2019;19(1):166. doi:10.1186/s12884-019-2312-9

41. Nahar D, Soni G, Chand AE, Mourya S. Bacterial etiology and their antibiogram in aerobic vaginitis patients at Tertiary Care Hospital, Kota, Rajasthan. Int J Scien Stud. 2016;4(3):103-107.
42. Donders GG, Vereecken A, Bosmans E, Dekeersmaecker A, Salembier G, Spitz B. Definition of a type of abnormal vaginal flora that is distinct from bacterial vaginosis: aerobic vaginitis. BJOG. 2002;109(1):34-43. doi:10.1111/j.1471-0528.2002.00432.x

43. Krauss-Silva L, Almada-Horta A, Alves MB, Camacho KG, Moreira MEL, Braga A. Basic vaginal $\mathrm{pH}$, bacterial vaginosis and aerobic vaginitis: prevalence in early pregnancy and risk of spontaneous preterm delivery, a prospective study in a low socioeconomic and multiethnic South American population. BMC Pregnancy Childbirth. 2014;14(1):107. doi:10.1186/1471-2393-14-107

44. Akomoneh EA, Foche FF, Aseneck CA, Abong RA, Ajonina MU. Prevalence of bacterial vaginosis among sexually active women attending the CDC central clinic Tiko, south west region, Cameroon. African J Infect Dis. 2016;10(2):96-101. doi:10.21010/ajid.v10i2.4

45. Demba E, Morison L, Van der Loeff MS, et al. Bacterial vaginosis, vaginal flora patterns and vaginal hygiene practices in patients presenting with vaginal discharge syndrome in The Gambia, West Africa. BMC Infect Dis. 2005;5(1):12. doi:10.1186/1471-2334-5-12

46. Casari E, Ferrario A, Morenghi E, Montanelli A. Gardnerella, Trichomonas vaginalis, Candida, Chlamydia trachomatis, Mycoplasma hominis and Ureaplasma urealyticum in the genital discharge of symptomatic fertile and asymptomatic infertile women. New Microbiol. 2010;33(1):69.

47. Venter H, Mowla R, Ohene-Agyei T, Ma S. RND-type drug efflux pumps from Gram-negative bacteria: molecular mechanism and inhibition. Front Microbiol. 2015;6:377. doi:10.3389/fmicb.2015.00377

48. Mulu W, Yimer M, Zenebe Y, Abera B. Common causes of vaginal infections and antibiotic susceptibility of aerobic bacterial isolates in women of reproductive age attending at Felegehiwot referral Hospital, Ethiopia: a cross sectional study. BMC Women's Health. 2015;15(1):42. doi:10.1186/s12905-015-0197-y

49. Mumtaz S, Ahmad M, Aftab I, Akhtar N. ul Hassan M, Hamid A. Aerobic vaginal pathogens and their sensitivity pattern. J Ayub Med Coll Abbottabad. 2008;20(1):113-117.

50. Howe R, Bitew A, Dagnew M, Tegenie B, Yeshitila B, Abate E. Bacterial profile, antibacterial susceptibility pattern and associated factors among women attending antenatal and postnatal health service at University of Gondar teaching Hospital, Northwest Ethiopia. Ethiop Med J. 2019.

51. Alemu A, Moges F, Shiferaw Y, et al. Bacterial profile and drug susceptibility pattern of urinary tract infection in pregnant women at University of Gondar Teaching Hospital, Northwest Ethiopia. BMC Res Notes. 2012;5(1):197. doi:10.1186/1756-0500-5-197

52. Bitew Kifilie A, Dagnew M, Tegenie B, Yeshitela B, Howe R, Abate E. Bacterial profile, antibacterial resistance pattern, and associated factors from women attending postnatal health Service at University of Gondar teaching hospital, Northwest Ethiopia. Int J Microbiol. 2018;2018. doi:10.1155/2018/3165391

53. Akram M, Shahid M, Khan AU. Etiology and antibiotic resistance patterns of community-acquired urinary tract infections in JNMC Hospital Aligarh, India. Ann Clin Microbiol Antimicrob. 2007;6 (1):4. doi:10.1186/1476-0711-6-4

54. Linhares I, Raposo T, Rodrigues A, Almeida A. Frequency and antimicrobial resistance patterns of bacteria implicated in community urinary tract infections: a ten-year surveillance study (2000-2009). BMC Infect Dis. 2013;13(1):19. doi:10.1186/1471-2334-13-19

55. Odonkor ST, Addo KK. Bacteria resistance to antibiotics: recent trends and challenges. Int J Biol Med Res. 2011;2(4):1204-1210.

56. Shrivastava SR, Shrivastava PS, Ramasamy J. World health organization releases global priority list of antibiotic-resistant bacteria to guide research, discovery, and development of new antibiotics. $J \mathrm{Med}$ Soc. 2018;32(1):76. doi:10.4103/jms.jms_25_17

57. Dobrut A, Gosiewski T, Pabian W, et al. The dynamics of vaginal and rectal Lactobacillus spp. flora in subsequent trimesters of pregnancy in healthy Polish women, assessed using the Sanger sequencing method. BMC Pregnancy Childbirth. 2018;18(1):350. doi:10.1186/ s12884-018-1987-7 
58. Imade GE, Musa J, Sagay AS, et al. Association of Bacterial vaginosis and other Sexually Transmitted Infections with HIV among pregnant women in Nigeria. Afr J Med Med Sci. 2014;43(Suppl 1):23.

59. French AL, Adeyemi OM, Agniel DM, et al. The association of HIV status with bacterial vaginosis and vitamin $\mathrm{D}$ in the United States. J Women's Health. 2011;20(10):1497-1503. doi:10.1089/jwh.2010.2685

60. Emiru AA, Alene GD, Debelew GT. The role of maternal health care services as predictors of time to modern contraceptive use after childbirth in Northwest Ethiopia: application of the shared frailty survival analysis. PLoS One. 2020;15(2):e0228678. doi:10.1371/journal.pone. 0228678
61. Adelaiye SM, Shittu S, Olayinka A. Characterization of bacterial vaginosis among HIV-positive and HIV-negative pregnant women. Int $J$ Biomedicine. 2015;5(3):141-146. doi:10.21103/Article5(3) OA6

62. Babu BV, Kar SK. Domestic violence against women in eastern India: a population-based study on prevalence and related issues. BMC Public Health. 2009;9(1):129. doi:10.1186/1471-2458-9-129

63. Madhivanan P, Krupp K, Chandrasekaran V, et al. Prevalence and correlates of bacterial vaginosis among young women of reproductive age in Mysore, India. Indian J Med Microbiol. 2008;26(2):132. doi:10.1016/S0255-0857(21)01928-9

\section{Publish your work in this journal}

Infection and Drug Resistance is an international, peer-reviewed openaccess journal that focuses on the optimal treatment of infection (bacterial, fungal and viral) and the development and institution of preventive strategies to minimize the development and spread of resistance. The journal is specifically concerned with the epidemiology of antibiotic resistance and the mechanisms of resistance development and diffusion in both hospitals and the community. The manuscript management system is completely online and includes a very quick and fair peerreview system, which is all easy to use. Visit http://www.dovepress.com/ testimonials.php to read real quotes from published authors. 